\title{
EFFECTS OF SEMINAL PLASMA ON THE FERTILIZING CAPACITY OF RABBIT SPERMATOZOA IN RELATION TO THE TIME OF OVULATION
}

\author{
M. G. CHANG, A. HANADA* AND DOROTHY M. HUNT \\ Worcester Foundation for Experimental Biology, Inc., \\ Shrewsbury, Massachusetts 01545, U.S.A.
}

(Received 29th March 1971)

In spite of advancement in the knowledge of the biochemistry of semen (White $\&$ Macleod, 1963; Mann, 1965), the physiological significance of seminal plasma for the fertilizing capacity of spermatozoa, except as a vehicle for sperm transport, is still obscure. When superovulated rabbits were inseminated with a minimal effective number of rabbit spermatozoa suspended in fructose Ringer solution or in rabbit seminal plasma, there was no significant difference in the proportion of eggs fertilized. When these sperm suspensions were allowed to stand at room temperature for $1 \mathrm{hr}$ before insemination, however, the proportion of eggs fertilized was significantly higher for the spermatozoa suspended in rabbit seminal plasma (Chang, 1949). The present experiment was designed to determine whether seminal plasma, due to its various contents, might be beneficial for sperm transport when insemination was carried out at the time of ovulation and whether seminal plasma could prolong the fertilizing life of spermatozoa in vitro or in the female tract.

Mature female rabbits of mixed breeds (mostly New Zealand White) purchased from local farms were caged separately for at least 3 weeks before use. Four sexually active males were vasectomized for the collection of seminal plasma by means of an artificial vagina. Two or three drops of semen, squeezed by means of a pair of forceps from one cauda epididymidis and vas deferens of seven males, were suspended in 1 to $2 \mathrm{ml}$ of undiluted seminal plasma, Ringer solution (without glucose), or Tyrode solution. After estimation of the number of spermatozoa in each suspension by means of a haemocytometer and adjustment to the required number for insemination, $0.5 \mathrm{ml}$ of the sperm suspension was inseminated into the vagina of each doe. Insemination was carried out within $50 \mathrm{~min}$ of semen collection. In two experiments, sperm suspensions were incubated aerobically in Carrel flasks at $37^{\circ} \mathrm{C}$ and gently rotated for $3 \mathrm{hr}$ before insemination. Antibiotics were not added to the sperm suspensions but antiseptic precautions were taken and blood contamination was avoided. Only samples containing spermatozoa of good motility after incubation were used.

Four to six does were inseminated at a time. An intravenous injection of 50 to $90 \mathrm{i} . \mathrm{u}$. HCG (Follutein, Squibb) induced ovulation $10 \mathrm{hr}$ later. The does were injected (a) $10 \mathrm{hr}$ before insemination (i.e. insemination took place at the time

\footnotetext{
* Fellow of Japanese Government.
} 
of ovulation), (b) soon after insemination (i.e. insemination took place about $10 \mathrm{hr}$ before ovulation) or (c) $20 \mathrm{hr}$ after insemination (i.e. insemination took place about $30 \mathrm{hr}$ before ovulation). They were killed $24 \mathrm{hr}$ after the injection of HCG and their eggs were recovered from the Fallopian tubes, mounted on slides and stained (Chang, 1952) for the assessment of fertilization.

It was thought that seminal plasma might stimulate the contraction of the female tract so that the sperm transport could be hastened. When a group of rabbits was inseminated at the time of induced ovulation (first row, Table 1), the percentage of fertilized eggs was significantly lower $(P<0.01)$ with sperm suspensions in Ringer solution than with those in Tyrode solution or in undiluted seminal plasma. The slightly higher proportion of fertilized eggs following insemination of sperm suspensions in Tyrode solution compared with those

TABLE 1

EFFECTS OF SEMINAL PLASMA ON THE FERTILIZING GAPACITY OF RABBIT SPERMATOZOA FROM VAS DEFERENS AND EPIDIDYMIS

\begin{tabular}{|c|c|c|c|c|c|c|}
\hline \multirow[b]{2}{*}{$\begin{array}{l}\text { Time of } \\
\text { insemination }\end{array}$} & \multirow{2}{*}{$\begin{array}{c}\text { Media } \\
\text { for } \\
\text { spermatozoa }\end{array}$} & \multirow{2}{*}{$\begin{array}{l}\text { No. } \\
\text { of } \\
\text { does }\end{array}$} & \multirow{2}{*}{$\begin{array}{c}\text { No. of sperm. } \\
\text { inseminated } \\
\left(\times 10^{6} / \text { doe }\right)\end{array}$} & \multirow{2}{*}{$\begin{array}{c}\text { No. of does } \\
\text { with } \\
\text { fertilized eggs }\end{array}$} & \multicolumn{2}{|c|}{ No. of eggs ( $\%$ fertilization $)$} \\
\hline & & & & & Total & $\begin{array}{l}\text { From does with } \\
\text { fertilized eggs }\end{array}$ \\
\hline $\begin{array}{l}\text { At the } \\
\text { time of } \\
\text { ovulation }\end{array}$ & $\begin{array}{l}\text { Ringer } \\
\text { Tyrode } \\
\text { Seminal plasma }\end{array}$ & $\begin{array}{l}6 \\
4 \\
6\end{array}$ & $\begin{array}{l}25 \text { to } 105 \\
58 \text { to } 140 \\
27 \text { to } 125\end{array}$ & $\begin{array}{l}4 \\
4 \\
6\end{array}$ & $\begin{array}{l}50(20 \%) \\
39(90 \%) \\
55(73 \%)\end{array}$ & $\begin{array}{l}31(32 \%) \\
39(90 \%) \\
55(73 \%)\end{array}$ \\
\hline $\begin{array}{l}10 \mathrm{hr} \text { before } \\
\text { ovulation }\end{array}$ & $\begin{array}{l}\text { Ringer } \\
\text { Seminal plasma }\end{array}$ & $\begin{array}{l}6 \\
6\end{array}$ & $\begin{array}{l}38 \text { to } 164 \\
34 \text { to } 133\end{array}$ & $\begin{array}{l}4 \\
5\end{array}$ & $\begin{array}{l}52(77 \%) \\
56(80 \%)\end{array}$ & $\begin{array}{l}41(98 \%) \\
46(98 \%)\end{array}$ \\
\hline $\begin{array}{l}10 \mathrm{hr} \text { before } \\
\text { ovulation* }\end{array}$ & $\begin{array}{l}\text { Tyrode } \\
\text { Seminal plasma }\end{array}$ & $\begin{array}{l}6 \\
6\end{array}$ & $\begin{array}{l}26 \text { to } 50 \\
26 \text { to } 50\end{array}$ & $\begin{array}{l}6 \\
5\end{array}$ & $\begin{array}{l}59(97 \%) \\
48(54 \%)\end{array}$ & $\begin{array}{l}59(97 \%) \\
36(72 \%)\end{array}$ \\
\hline $\begin{array}{l}30 \mathrm{hr} \text { before } \\
\text { ovulation }\end{array}$ & $\begin{array}{l}\text { Ringer } \\
\text { Seminal plasma }\end{array}$ & $\begin{array}{l}6 \\
6 \\
6 \\
6\end{array}$ & $\begin{array}{l}15 \text { to } 19 \\
44 \text { to } 129 \\
16 \text { to } 18 \\
73 \text { to } 88\end{array}$ & $\begin{array}{l}2 \\
2 \\
1 \\
2\end{array}$ & $\begin{array}{l}58(17 \%) \\
64(27 \%) \\
58(7 \%) \\
54(20 \%)\end{array}$ & $\begin{array}{l}13(77 \%) \\
21(81 \%) \\
10(40 \%) \\
22(48 \%)\end{array}$ \\
\hline
\end{tabular}

* Incubated in vitro at $37^{\circ} \mathrm{C}$ for $3 \mathrm{hr}$ before insemination.

in undiluted seminal plasma suggests that the seminal plasma was not beneficial for sperm transport. The low proportion of fertilized eggs obtained using spermatozoa suspended in Ringer solution was probably due, therefore, to the lack of an energy source for the maintenance of sperm integrity.

Inseminations of epididymal spermatozoa suspended in Ringer solution or in undiluted seminal plasma were carried out in another group of rabbits immediately before the injection of HCG, about $10 \mathrm{hr}$ before ovulation as in the normal sequence of mating (second row, Table 1). There was no significant indication of an advantage of seminal plasma over Ringer solution. However, when the samples were incubated at $37^{\circ} \mathrm{C}$ for $3 \mathrm{hr}$ before insemination (third row, Table 1), the percentage of fertilized eggs was significantly lower $(P<0.01)$ with sperm suspensions in seminal plasma than with those in Tyrode solution. This revealed an adverse effect of seminal plasma for the maintenance of spermatozoa in vitro at body temperature.

Epididymal spermatozoa suspended in Ringer solution or in undiluted 
seminal plasma were inseminated in another group of rabbits $20 \mathrm{hr}$ before the injection of HCG, in order to determine whether seminal plasma could prolong the fertilizing life of spermatozoa in the female tract (fourth row, Table 1). For the total number of eggs examined, there was no significant difference in the percentage of fertilized eggs recovered from does receiving sperm suspensions in Ringer solution or in seminal plasma. When the results from the rabbits that had fertilized eggs were compared, the percentage of fertilized eggs was significantly higher $(P<0 \cdot 05)$ for does inseminated with spermatozoa suspended in Ringer solution than for those receiving seminal plasma sperm suspensions. Again, seminal plasma did not appear to be beneficial in prolonging the fertilizing life of spermatozoa in the female tract. Since the low proportion of eggs fertilized by insemination with spermatozoa suspended in Ringer solution at the time of ovulation can be attributed to the lack of energy source (first row, Table 1), it seems that the fertilizing capacity of spermatozoa must be capable of being maintained for a long while by the energy sources supplied from the female tract. Thus, so far as can be determined in the present study, the seminal plasma does not seem to play an important rôle for the maintenance of the fertilizing capacity of rabbit spermatozoa.

This study was supported by grants from the U.S. Public Health Service (HD 03003) and the Ford Foundation.

\section{REFERENCES}

Chang, M. C. (1949) Effects of heterologous seminal plasma and sperm cells on fertilizing capacity of rabbit spermatozoa. Proc. Soc. exp. Biol. Med. 70, 32.

Chang, M. C. (1952) Fertilizability of rabbit ova and the effects of temperature in vitro on their subsequent fertilization and activation in vivo. F. exp. Zool. 121, 351.

MANN, T. (1965) Biochemistry of semen and of the male reproductive tract. Methuen, London.

White, I. G. \& MACLEOD, J. (1963) Composition and physiology of semen. In: Mechanisms Concerned with Gonception. Ed. G. G. Hartman. Macmillan (Pergamon Press book), New York. 